\title{
Biological and pathogenetic characterization of different isolates of murine gammaherpesvirus 68 (MHV-68) in the context of study of human oncogenic gammaherpesviruses
}

\author{
J. ČIPKOVÁ-JARČUŠKOVÁ ${ }^{1}$, A. CHALUPKOVÁ ${ }^{1}$, Z. HRABOVSKÁ ${ }^{1}$, M. WÁGNEROVÁ ${ }^{1}$, J. MISTRÍKOVÁ ${ }^{1,2^{*}}$
}

${ }^{1}$ Department of Microbiology and Virology, Faculty of Natural Sciences, Comenius University, Mlynská dolina CH-2, 84215 Bratislava, Slovak Republic; ${ }^{2}$ Institute of Virology, Slovak Academy of Sciences, Dúbravská cesta 9, 84505 Bratislava, Slovak Republic

\begin{abstract}
Summary. - Study of murine gammaherpesvirus 68 (MHV-68), which was discovered in 1980 in Slovakia, has led to many important findings regarding gammaherpesviral properties in general. Nowadays, it is considered to be a universal model used for detailed studies to determine pathogenetic, immunological and molecular aspects of oncogenesis in analogy to Epstein-Barr virus (EBV) and Kaposi's sarcoma-associated virus (KSHV). The objective of this work is to characterize biological and pathogenetic properties of the virus with an emphasis on our prior results concerning ecology, epidemiology, viral persistence in peritoneal macrophages, detection of malign and benign lymphoproliferations accompanied by the presence of atypical lymphocytes in blood during IM-like and leukemia-like syndromes. We are trying to elucidate the role of virus-specific genes in virulence, pathogenicity and murine gammaherpesvirus oncogenesis by comparison of molecular-biological, pathogenetic and oncogenic potential of MHV-68 isolates and deletion mutant MHV-76 and therefore help to understand the analogical processes that occur in EBV infected patients.
\end{abstract}

Keywords: murine gammaherpesvirus 68; virus isolates; pathogenesis; deletion mutant; EBV

\section{Contents:}

1. History of virus isolation

2. Ecology and epidemiology of murine gammaherpesvirus(es)

3. Biological characterization of different of murine gammaherpesvirus isolates

4. Pathogenetic, immunological and oncogenetic characterization of murine gammaherpesvirus isolates

5. Usefulness of animal model for studying human gammaherpesviruses

*Corresponding author. E-mail: virumis@savba.sk; phone: +4212-54773172.

Abbreviations: EBV = Epstein-Barr virus; ICTV = International Committee on Taxonomy of Viruses; KSHV = Kaposi's sarcomaassociated herpesvirus; MHV-60, MHV-68, MHV-72, MHV-76, MHV-78, and MHV-Šumava = murine gammaherpesvirus 60, $68,72,76,78$, and Šumava; MuHV-4 = murid herpesvirus 4; post infection = p.i.; REF = rabbit embryo cell

\section{History of virus isolation}

The history of novel murine gammaherpesvirus dates back to 1980, when several herpesvirus strains (designated MHV-60, MHV-72, MHV-76, MHV-78, and MHV-Šumava) were isolated from the bank vole Clethrionomys glareolus (today Myodes glareolus) and from another wild rodent Apodemus flavicollis in two distant regions of the Czech and Slovak Federative Republic (Blaškovič et al., 1980; Mistríková and Blaškovič, 1985), and isolates MHV-4556 and MHV-5682 (Kožuch et al., 1993). It was later found that MuHV-4 is endemic in wood mice (Apodemus sylvaticus), but not in two species of voles (Myodes glareolus, Microtus agrestis) (Blasdell et al., 2003). Previously published data (partial biological, morphological and pathogenetic studies indicating neurotropism and latency in Gasserian ganglion) suggested that murine gammaherpesvirus belongs to the alphaherpesvirus subgroup (Čiampor et al., 1981; Svobodová et al., 1982a,b; Blaškovič et al., 1984; Rajčáni et al., 1985). Surprisingly, when Efstathiou et al. (1990a,b) investigated the genome of MHV-68 they identified nine genes which 
Table 1. Cell lines permissive for growth of all murine gammaherpesvirus isolates

\begin{tabular}{|c|c|c|c|}
\hline Cell line & Origin & $\begin{array}{c}\text { Log. of infect. } \\
\text { titer }\end{array}$ & $\begin{array}{c}\mathrm{CPE} \\
\text { (days p.i.) }\end{array}$ \\
\hline KEB & Chicken & 2 & 3 \\
\hline LB & Mouse & 5.5 & 2.3 \\
\hline $\mathrm{KrOb}$ & Rabbit & 3 & 4.5 \\
\hline SIRC & Rabbit & 3 & 3.75 \\
\hline $\mathrm{ZP}$ & Hare & 3 & 4 \\
\hline REF & Rabbit & 7 & 2.5 \\
\hline BHK-21 & Hamster & 6 & 5.5 \\
\hline MJ & Guinea pig & 3 & 5.1 \\
\hline CCL-64 & Mink & 2 & 3 \\
\hline PS & Swine & 4 & 5 \\
\hline GMK & Monkey & 3 & 2.5 \\
\hline Vero & Monkey & 4.5 & 3.5 \\
\hline Am-57 & Human & 3 & 4 \\
\hline $\mathrm{HeLa}$ & Human & 2 & 4 \\
\hline LEP & Human & 2 & 3.5 \\
\hline NIH 3T3 & Mouse & 6 & 2 \\
\hline NB-78 & Tumor ${ }^{*}$ & ND & ND \\
\hline $293 \mathrm{~T}$ & Human & ND & ND \\
\hline NMuMg & Mouse & 3 & 3.5 \\
\hline MEF & Mouse & 3.5 & 3 \\
\hline RAT & Rat & 4.5 & 4 \\
\hline NS0 & Mouse & ND & ND \\
\hline SP2 & Mouse & ND & ND \\
\hline PM & Mouse & ND & ND \\
\hline
\end{tabular}

Cell line derived from tumor of MHV-78 infected mouse. ND = not done.

encoded amino acid sequence with greater similarity to proteins of the gammaherpesviruses EBV and herpesvirus saimiri, than to the homologous products of the alphaherpesviruses varicella-zoster and herpes simplex type I or the betaherpesvirus human cytomegalovirus (Efstathiou et al., 1990a,b). Antigenic profiles of all isolates have been compared with each other using polyclonal antibodies (antisera) without detecting any significant differences (Svobodová et al., 1982b). More detailed comparative analysis of antigen properties of isolates was carried out with monoclonal antibodies specific for murine gammaherpesvirus. Immunoanalysis by ELISA showed a close antigenic relationship between the isolates, nevertheless, some antigenic individuality in immunodominant proteins were found (Matušková et al., 2003). DNA of MHV-68 has sequences homologous to EBV, KSHV, and HVS (GenBank Acc. No. U 97553) is a linear double stranded DNA molecule, which contains 118,237 bp of unique sequence, flanked by multiple copies of terminal repeats with a total length of 1,213 bp (Virgin et al., 1997). MHV-68 was classified by the International Committee on Taxonomy of Viruses in 1995 to the species Murid herpesvirus 4 (MuHV-4) (Murphy et al., 1995). Ac- cording to the latest ICTV report, it belongs to the genus Rhadinovirus, the subfamily Gammaherpesvirinae, the family Herpesviridae and the order Herpesvirales (Davison et al., 2009). The most studied gammaherpesviruses are human herpesvirus 4 (Epstein-Barr virus) and human herpesvirus 8 (Kaposi's sarcoma-associated herpesvirus), which are associated with a range of cancers. Since these viruses have no well-established in vivo infection model, related animal gammaherpesviruses are an important source of information.

\section{Ecology and epidemiology of murine gammaherpesvirus(es)}

MHV-68 is a natural pathogen of free living murid rodents, isolated from Myodes glareolus and Apodemus flavicollis. Neutralizing antibodies were found in sera from animals of other species living with infected rodents in the same biotope. Complement-fixing antibodies were detected in sera of Apodemus flavicollis, Myodes glareolus, Microtus arvalis and Mus musculus (Mistríková and Blaškovič, 1985), and in later study in sera of Apodemus sylvaticus, Microtus agrestis also (Blaškovič et al., 1987). In order to prove the presence of murine gammaherpesvirus in rodents, their blood was tested by specific PCRs (Klempa et al., 2001). The shedding of virus by breast milk at 4 days post infection (p.i.) and by urine, saliva and tears at 14 days p.i. was experimentally confirmed by Hricová and Mistríková (2008). Later, vertical route of transmission in mice was confirmed, as well as teratogenicity of the virus (Štiglincová et al., 2011). A long term study of MHV-68 antibodies in mixed population of Myodes glareolus and Apodemus sylvaticus in UK (Telfer et al., 2007) revealed their higher prevalence in the latter host, thereby supporting a previous view that Apodemus sylvaticus is the major natural host of MHV-68, even though this virus was originally isolated from Myodes glareolus. An investigation of incidence of 13 different viruses in Mus domesticus in the UK using serology (Becker et al., 2007) showed the seroprevalence of MHV-68 antibodies at level 3-13\%. All this data has led to the conclusion that MHV-68 infects in the nature various rodent species belonging to diverse, phylogenetically distant families and to the hypothesis that it could be transmitted from infected rodents to other animals living in common biotopes. Study performed in this context has brought evidence of virus-neutralizing MHV-68 antibodies in the serum of fallow deer, wild boars, deer, sheep, foxes and muflons (Marková et al., 2007; Hamzová et al., 2005; Mistríková et al., 2000) as well as in humans (laboratory personnel working with MHV-68 or wild rodents, hunters, general population) (Hricová and Mistríková 2007; Marková et al., 2007; Mistríková et al., 2000, 2006). In spite of the facts mentioned above, the transmission of MHV- 
68 from murine rodents to other animals and humans has not been proved.

\section{Biological characterization of different murine gammaherpesvirus isolates}

In contrast to most gammaherpesviruses, MHV-68 forms a fully productive infection in conventional cell cultures. More than twenty cell lines of different origin (mouse, chick, rabbit, hamster, mink, swine, guinea pigs, monkey, man), especially primary or diploid embryonic cells, were able to reproduce all isolates of $\mathrm{MHV}-68$, reaching titres ranged Log. 2-7, resembled those obtained with human herpesviruses 1 and 2, pseudorabies and guinea pig herpes-like virus (Hsiung-Kaplow virus) in the identical cell line (Svobodová et al., 1982a) (Table 1).

Cytomorphology of rabbit embryo cell (REF) cultures infected with MHV-68 was characterized first of all by cell rounding. Further foci of necrotic cells appeared gradually by total destruction of the monolayer. The nuclei of some cells contained Cowdry type A inclusions with a typical bright halo. The changes in nuclei resembled those of herpetic cell infection: margination of chromatin, disintegration of nucleoli, some nuclei became eosinophilic. At a later stage of infection, complete destruction of cytoplasm was observed in the cells. Infection of other cell lines with all herpesvirus isolates led to polykaryocyte formation. Some nuclei of polykaryocytes contained one or several typical inclusion bodies or revealed disintegrated nucleoli with marginated chromatin. Lobulated nuclei were no exception (Fig. 1) (Vero cells infected with MHV-72). Murine gammaherpesvirus can persist in cell lines of B-lymphocytes origin. Furthermore, MHV-68 strain established a persistent infection in mouse myeloma cells and NS0 cell line (Sunil-Chandra et al., 1993). Not only mouse B-cell lines (SP2/0 and NS0) were confirmed to be permissive for murine gammaherpesvirus in vitro, but mouse peritoneal macrophages also (Mistríková et al., 1994; Spiššáková et al., 2005). The role of macrophages in MuHV-4 spreading was recognized for the first time when adherent lung or peripheral blood mononuclear cells (mainly macrophages) were found to participate in virus dissemination during acute infection with the MHV-72 isolate (Mistríková et al., 1994). Electron microscopy of the cells infected with each of the murine gammaherpesvirus isolates revealed similar morphological changes and characteristic features of those, which developed during herpesvirus infection of REFs. The ultrastructural changes in cells infected with all isolates resembled those find in freshly isolated human herpesvirus 1, but some morphological changes displayed cytomegalovirus characteristics (Čiampor et al., 1981). Growth of MHV-68 in different cell cultures is illustrated by comparison of growth curves of all isolates (Fig. 2).

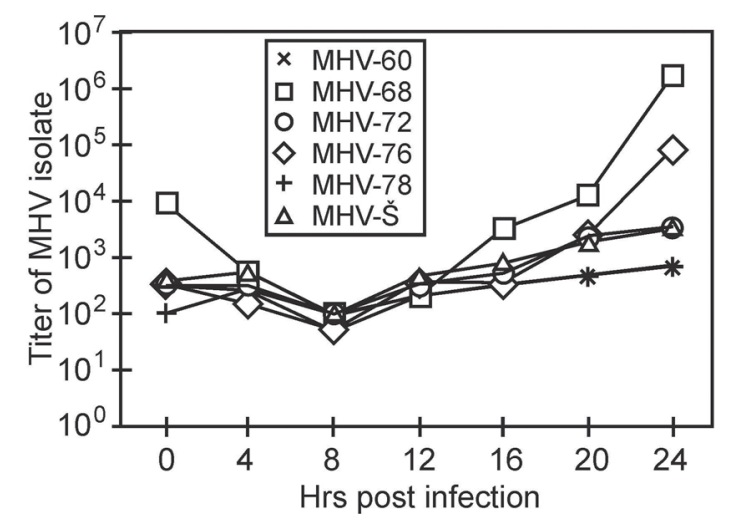

Fig. 1

Comparison of growth curves of all murine gammaherpesvirus isolates

4. Pathogenetic, immunological and oncogenetic characterization of murine gammaherpesvirus isolates

The first pathogenetic experiment was realized during primary isolation of MHV-68, when newborn laboratory mice with different organ suspensions (from lung, spleen, heart, liver and kidney) of wild rodents were intracerebrally inoculated, and these mice developed fatal encephalitis at 10 day p.i. (Blaškovič et al., 1980).

Pilot pathognetic study was done on newborn laboratory mice using the most authentic routes of infection, peroral and intranasal. Virus spreads quickly to lungs (necrotizing pneumonia), liver, spleen, kidneys, heart muscle, striated muscles and spinal ganglia (Blaškovič et al., 1984). In juvenile and adult outbred mice, which were infected with various doses of MHV-68 and MHV-72, hematogenous dissemination from lungs to heart muscle, spleen, liver, thymus and kidneys was demonstrated by virus titration and immunofluorescence (Rajčáni et al., 1985). Replication of murine gammaherpesvirus in capillary endothelium cells within the damaged alveolar septa was confirmed by electron microscopy. Additional studies demonstrated the absence of neural MHV-68 spreading to Gasserian ganglia. Chronic (persistent) infection of lungs, spleen and kidneys was established in survived mice after acute virus infection. Trigeminal ganglia also became involved via bloodstream (Rajčáni et al., 1987). The spread of murine gammaherpesvirus to the spleen was accompanied by notable splenomegaly and the number of spleen cells increased two to threefold (Sunil-Chandra et al., 1992; Ehtisham et al., 1993; Mistríková et al., 1994); (Fig. 3). The spleen appeared to be a major site of MHV-68 persistence when lymphocytes were detected to be latently infected up to 90 days p.i. During the primary infection, the atrophy of the thymus and spleen of clinically sick animals was observed. In contrast, in asymptomatic animals lym- 


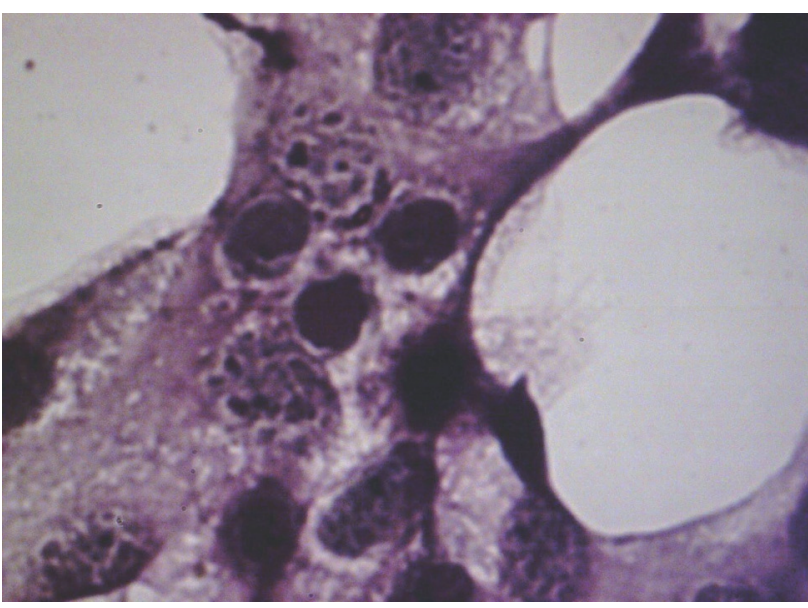

Fig. 2

Vero cells infected with MHV-72

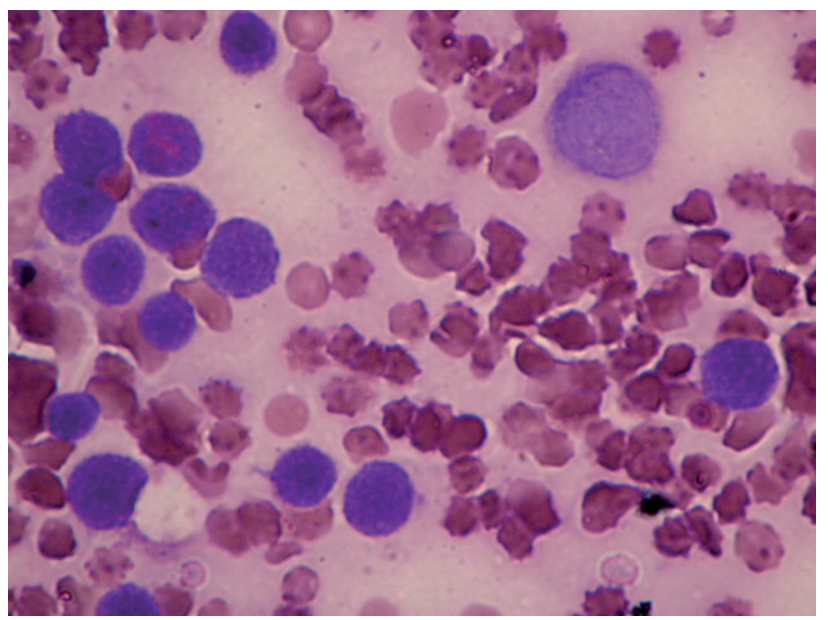

Fig. 3

Atypical cells in blood of MHV-72 infected Balb/c mice during IM-like or leukemia-like syndrome

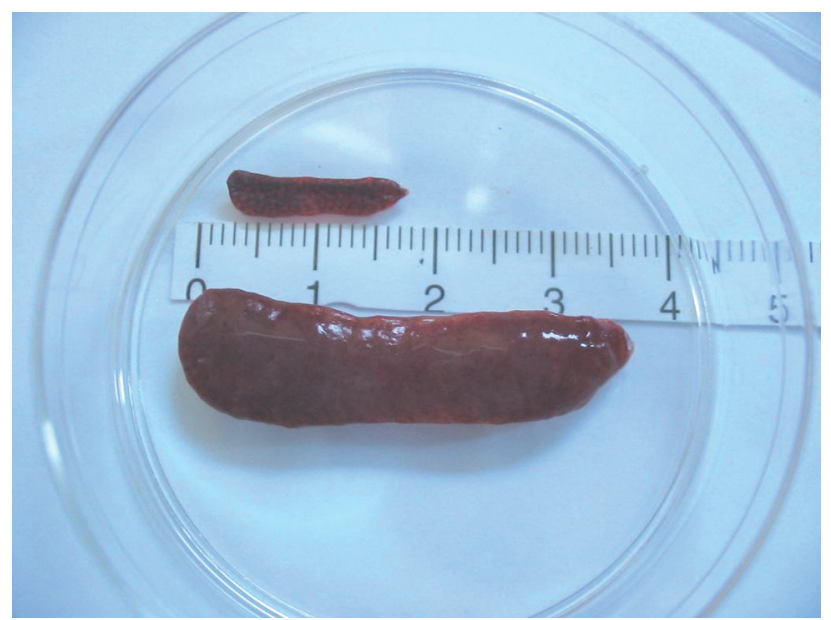

Fig. 4

Splenomegaly after MHV-72 infection of Balb/c mice phoproliferative responses, typified by splenomegaly, were relatively frequent (Sunil-Chandra et al., 1992; Mistríková et al., 1994, 1996a, 1998, 2000, 2002, 2004). After intranasal inoculation of Balb/c mice with $\mathrm{MHV}-72$, the virus persisted in adherent lung mononuclear cells (AMC). Infectious virus was occasionally detected during a period of eight months after infection in lymphatic organs (thymus, spleen, and lymph nodes), bone marrow, alveolar and peritoneal AMC, lymphocytes and macrophages of peripheral blood by indirect immunofluorescence and co-cultivation with permissive Vero cells. Virus neutralizing antibodies were detected during a one year period in the sera of infected mice, and their levels correlated with reactivation of the latent MHV-72 (Mistríková et al., 1994). During latency of MHV-68 in different haematopoetic cells, B-cells play a crutial role in regulating $\mathrm{MHV}-68$ reactivation from latency and therefore significantly control chronic infection (Weck et al., 1999a, b). Infected cells can also be detected in lymph nodes and bone marrow (Nash et al., 1996). Peritoneal macrophages have been identified as a further reservoir for latent MHV-72 (Mistríková et al., 1994) as well as MHV-68 (Weck et al., 1999a). Lung epithelial cells are a major site of gammaherpesvirus latency (Stewart et al., 1998). Mice inoculated intranasally with MHV-68 established a productive infection in the lungs in alveolar epithelial cells, causing an interstitial and peribronchial pneumonia. This productive infection lasts for around 10 days; by that time virus was spreading via lymph nodes to the spleen, where it established latency, predominantly in B-cells (Stewart et al., 1998). This initial latent infection in the spleen with an intense lymphoproliferation of B-cells and T-cells led to splenomegaly. Although the precise mechanisms underlying splenomegaly are still being elucidated, it is clear, that infected B-cells and CD4+ helper T-cells are critical to this process. It was also proven that a number of cytokines are abundantly secreted, creating a cytokine storm, that certainly contributes to lymphoproliferation. Latently infected cells appear in the first week post-infection, reach peak levels during the second to third week before declining to a basal level which is maintained indefinitely in the host. As during most viral infections, T-cells are critical for the immune-mediated resolution of infection. A common feature of gammaherpesvirus infection is the genesis of lymphoproliferative disorders. We proved experimental reactivation of latent MHV-72 infection as well as an increased lymphoproliferation following immunosuppression with FK-506 (Mistríková et al., 1996a, 1999). Chronic infection of Balb/c mice with MHV-60, 68, 72, 78, and Šmava is associated with neoplasm development. We described the oncogenic potential of all murine gammaherpesvirus isolates in vivo and in vitro as well (Mistríková et al., 1996b, 2002; Oda et al., 2005; Mrmusová-Šupolíková et al., 2003; Pappová et al., 2004). Through pathogenetic characterization of a deletion mutant MHV-76 we sug- 
Table 2. Detection of tumors in correlation with deletion of M4 gene

\begin{tabular}{lccl}
\hline MHV-isolates & Oncogenicity (\%) & $\begin{array}{c}\text { Presence of virus-specific } \\
\text { genes }\end{array}$ & References \\
\hline MHV-60 & $22 \%$ & M1-M4 & Pappová et al. (2004); Jarčušková et al. (unpublished data) \\
MHV-68 & $9 \%$ & M1-M4 & Sunil-Chandra et al. (1994); Virgin et al. (1997) \\
S11 $\left(10^{6}\right)$ & $16,6 \%$ & $\mathrm{ND}$ & Usherwood et al. (1996b) \\
S11 $\left(10^{7}\right)$ & $50 \%$ & $\mathrm{ND}$ & Usherwood et al. (1996b) \\
MHV-72 & $11 \%$ & $\mathrm{M} 4$ & Mistríková et al. (1996b); Oda et al. (2005) \\
MHV-76 & - & - & Chalupková et al. (2008); Macrae et al. (2001) \\
MHV-78 & $7 \%$ & M1-M4 & Mrmusová-Šupolíková et al. (2003); Mistríková et al. \\
& & (2006) & Mistríková et al. (2006); Hrabovská et al. (2010a) \\
NB-78 & $23,5 \%$ & M1-M4 & Mistríková et al. (2002); Blaškovičová et al. (2007) \\
MHV-Š & $14,6 \%$ & M4
\end{tabular}

gested a possible association of M4 gene with oncogenic potential of the virus (Macrae et al., 2001; Mistríková and Rajčáni, 2008; Chalupková et al., 2008) (Table 2). Several cell lines were derived from murine gammaherpesvirusinfected mice with lymphoproliferative disorders. Four of these were MHV-68 negative. Cell line designated S11 was a B-lymphocyte origin and was found to contain MHV- 68 genome molecules in both linear and episomal forms and to be capable of reactivating the virus. This first naturally occuring MHV-68 positive B-cell line is an invaluable tool for the study of murine gammaherpesvirus-latency (Usherwood et al., 1996b). We derived another tumour cell line from the lymphoma of MHV-78 infected Balb/c mice and it was designated NB-78. This cell line harbours viral genome but produces infectious virus only rarely upon reactivation (Mistríková et al., 2006). NB-78 cell line served as a model for latent virus reactivation study in conditions with low oxygen concentration (Polčicová et al., 2008), to confirm the general hypothesis about the connection between the reactivation of latent gammaherpesviruses and malignant tumourigenesis (Hrabovská et al., 2010a,b). An important feature of either acute or chronic infection with all murine gammaherpesvirus isolates associated with limited virus replication are the lymphoproliferative changes of both $\mathrm{B}$ and $\mathrm{T}$ lymphocytes occurring in lungs, spleen (Usherwood et al., 1996a) and in the peripheral blood of Balb/c mice (Mistríková and Mrmusová, 1998). Lymphoproliferative infiltrating in the spleen and lungs consisted of a mix population of B- and T-cells (Sunil-Chandra et al., 1994). An IM-like syndrome may develop during acute post-infection intervals as well as during latency (Fig. 3). The syndrome occasionally resembles leukemia (Mistríková and Šupolíková, 1998; Rašlová et al., 2000; Mistríková et al., 2004). During IM-like syndrome, the number of CD8 cells increased. This increase correlated with an increase in the number of B-CD19 cells and NK cells (Mrmusová et al., 2002). During IM-like syndrome, the atypical cells in the blood of Balb/c mice were immunophe- notypized as CD8 and NK cells (Mrmusová et al., 2002), in the blood of athymic (nude) mice atypical B-cells were detected (Rašlová et al., 2000). We confirmed the capacity of MHV-60 and MHV-78 to induce malignant transformations and we proved the presence of viral DNA, antigen and infectious virus not only in tumours, but also in selected organs of infected mice. Finally, we investigated changes in the expression of virus genes (ORF50 and ORF73) during reactivation of latent virus. In the process of reactivation, expression of ORF73 (gene specific for latent phase) was stopped and an expression of ORF50 (gene specific for lytic phase) was induced. Our results contributed to the study of murine herpesvirus latency (as a model for the study of human gammaherpesviruses) which is often associated with oncogenesis (Hrabovská et al., 2010a,b).

\section{Usefulness of animal model for studying human gammaherpesviruses}

Gammaherpesviruses share an ability to transform lymphocytes causing lymphoproliferative disorders and malignancies in natural or experimental hosts. Infection of mice with the murine gammaherpesvirus MHV-68 has been developed as a small animal model system. This system has enabled the study of key aspects of gammaherpesvirus infection in a natural host, in particular the detailed study of the fundamentals of virus-host interactions. The pattern of infection observed in murine gammaherpesvirus infected mice is similar to that seen in an EBV infected man suffering from infectious mononucleosis. It is not yet known whether the mechanism of cell transformation observed in chronic murine gammaherpesvirus infection is similar to that of EBV. Murine gammaherpesvirus molecular and pathogenic similarities to EBV identify this virus as a useful model for the study of human diseases caused by EBV (Simas and Efstathiou, 1998; Stewart et al., 2005; Hughes et al., 2010). 
Table 3. Detection of virus-specific genes in MHV-68 isolates

\begin{tabular}{lccccl}
\hline $\begin{array}{l}\text { Gene/MHV } \\
\text { isolate }\end{array}$ & M1 & M2 & M3 & M4 & References \\
\hline MHV-60 & + & + & + & + & $\begin{array}{l}\text { Jarčušková et al. (unpublished } \\
\text { data) }\end{array}$ \\
MHV-68 & + & + & + & + & Virgin et al. $(1997)$ \\
MHV-72 & - & - & - & + & Oda et al. $(2005)$ \\
MHV-76 & - & - & - & - & Macrae et al. $(2001)$ \\
MHV-78 & + & + & + & + & Mistríková et al. $(2006)$ \\
MHV-Š & - & - & - & + & Blaškovičová et al. $(2007)$ \\
\hline
\end{tabular}

The exploration of murine gammaherpesvirus-mouse model should enable the in vivo study of issues such as the efficacy of vaccination against virus antigens and strategies and how to modulate the tumourigenicity of virus infected cells. Many research groups have identified the role of a number of MHV68 proteins during virus infection and discovered novel host proteins that are involved in host defense. Mouse model is helping to define the roles of many pathogenesis related virus proteins (Hughes et al., 2011; Arico et al., 2011). An additional benefit of murine gammaherpesvirus model is the ability to use transgenic knockout technology for studying the host immune system components involved in antiviral defense. The selection of virus specific proteins suitable as vaccines against gammaherpesviruses seems to be helpful for future potential immunotherapeutic strategies.

In our laboratory we have several isolates of MHV-68, which differ in their biological properties and oncogenetic potential. Using molecular analysis, we identified differences in their genomes with high variability at the left end, where nonessential virus-specific genes are located (Table 3). Infection with MHV-76 that has its left end locus deleted led to rapid productive infection clearance, attenuation in splenic infection and splenomegaly. Over an infection period of two years we detected no tumours, indicating that MHV-76 is probably the only non-oncogenic $\mathrm{MHV}$ isolate (Table 4). It is believed that M4 gene might be directly or indirectly involved in murine herpesvirus oncogenesis.

The aim of this work was to present MuHV-4 (synonyms: murine gammaherpesvirus 68, mouse herpesvirus strain 68, MHV-68), which was discovered in Slovakia from its isolation to biological characterization, cell tropism and replication in cell cultures, as well as in model organisms. Based on our results confirming the similarity of MHV-68 to another gammaherpesvirus-human oncogenic EBV, we were

Table 4. Comparison of pathogenetic properties of MHV-68 isolates

\begin{tabular}{|c|c|c|c|c|c|c|}
\hline Mouse species & M. glareolus & M. glareolus & M. glareolus & A. flavicollis & A. flavicollis & A. flavicollis \\
\hline Isolate/strain & MHV-60 & MHV-68 & MHV-72 & & & \\
\hline Tumor formation & $22 \%$ & $9 \%$ & $11 \%$ & none & $7 \%$ & $14,6 \%$ \\
\hline $\begin{array}{l}\text { Acute „IM-like“ } \\
\text { syndrome }\end{array}$ & $\begin{array}{c}30000 / \mu \mathrm{l} \\
26 \% \text { atypical }\end{array}$ & $\begin{array}{c}12700 / \mu l \\
14 \% \text { atypical }\end{array}$ & $\begin{array}{c}6300 / \mu l \\
10 \% \text { atypical }\end{array}$ & $\begin{array}{c}9000 / \mu l \\
9 \% \text { atypical }\end{array}$ & $\begin{array}{c}15000 / \mu \mathrm{l} \\
13 \% \text { atypical }\end{array}$ & $\begin{array}{c}15000 / \mu \mathrm{l} \\
15 \% \text { atypical }\end{array}$ \\
\hline $\begin{array}{l}\text { "Leukemia-like“ } \\
\text { syndrome }\end{array}$ & $\begin{array}{c}25000 / \mu l \\
12 \% \text { atypical PBC }\end{array}$ & $\begin{array}{c}9400 / \mu \mathrm{l} \\
6 \% \text { atypical PBC }\end{array}$ & $\begin{array}{c}118000 / \mu l \\
48 \% \text { atypical PBC }\end{array}$ & $\begin{array}{c}16800 / \mu \mathrm{l} \\
13 \% \text { atypical PBC } \\
\text { (no splenomegaly) }\end{array}$ & $\begin{array}{c}15000 / \mu 1 \\
9 \% \text { atypical PBC }\end{array}$ & $\begin{array}{c}500000 / \mu l \\
80 \% \text { atypical } \\
\text { PBC }\end{array}$ \\
\hline Splenomegaly & $60 \times 10^{6}$ (yes) & $30 \times 10^{6}$ (yes) & $52 \times 10^{6}$ (yes) & $20 \times 10^{6}($ no) & $60 \times 10^{6}$ (yes) & $50 \times 10^{6}$ (yes) \\
\hline $\begin{array}{l}\text { Virus growth at } \\
\text { intervals }\end{array}$ & 2-730 d.p.i. & 2-550 d.p.i. & 7-240 d.p.i. & 1-870 d.p.i. & 2-180 d.p.i. & 2-180 d.p.i. \\
\hline Brain & Negat. & $\begin{array}{l}11-21 \text { and } 150,180 \\
\text { d.p.i. }\end{array}$ & Negat. & $210,450,810$ d.p.i. & Negat. & Negat. \\
\hline Lungs & 2-7 d.p.i. & 4-14 d.p.i. & 2-28 d.p.i. & $\begin{array}{l}\text { 1-7 and } 150,270 \text {, } \\
330 \text { d.p.i. }\end{array}$ & 2-60 d.p.i. & 2-14 d.p.i. \\
\hline Thymus & 5 d.p.i. & 4-120 d.p.i. & 2-90 d.p.i. & 210 and 720 d.p.i. & 3-180 d.p.i. & 3-90 d.p.i. \\
\hline Spleen & $\begin{array}{c}3-10 \text { and } \\
550-730 \text { d.p.i. }\end{array}$ & 7-120 d.p.i. & 7-28 d.p.i. & 210-720 d.p.i. & 15-60 d.p.i. & 10-180 d.p.i. \\
\hline $\begin{array}{l}\text { Peritoneal } \\
\text { macrophages }\end{array}$ & Negat. & 7-60 d.p.i & 7-240 d.p.i. & 210 d.p.i. & 28-60 d.p.i. & 7-180 d.p.i. \\
\hline Bone marrow & Negat. & 4-21 and 60, 90 d.p.i. & 7-90 d.p.i. & $\begin{array}{l}150,270,330 \\
\text { and } 660 \text { d.p.i. }\end{array}$ & 15-120 d.p.i. & 7-180 d.p.i. \\
\hline Lymph nodes & Negat. & 10-90 d.p.i. & 10-28 d.p.i. & $\begin{array}{l}\text { 150, } 390 \text { and } \\
450 \text { d.p.i }\end{array}$ & 15-60 d.p.i. & ND \\
\hline Kidneys & 18-24 and 730 d.p.i. & 7-27 d.p.i. & Negat. & $\begin{array}{c}\text { 150, } 270,330,390, \\
450,720 \text { and } 810 \text { d.p.i. }\end{array}$ & 7-15 d.p.i. & Negat. \\
\hline Liver & Negat. & 7-17 d.p.i. & Negat. & 150-810 d.p.i. & Negat. & 180 d.p.i. \\
\hline VNT antibodies & $1: 512$ & $1: 128$ & $1: 1024$ & $1: 64$ & 1:128-256 & 1:256-512 \\
\hline
\end{tabular}

d.p.i. $=$ days post infection; IM-like $=$ infectious mononucleosis-like; $\mathrm{ND}=$ not done; $\mathrm{PBC}=$ peripheral blood cell; $\mathrm{VNT}=$ virus neutralization . 
able to interpret some processes observed with MHV-68 in analogy with those known on EBV. In particular, that were the processes occur in the course of MHV-68-induced persistent infection in mice, accompanied by tumour formation and leukemia following immunosuppression. These processes cannot be investigated at molecular, cellular or tissue level in humans. However, they can be followed on a model of Balb/c mice infected with MHV-68, which is nowadays generally accepted mainly due to the results described in this minireview.

Acknowledgement. This work was supported by VEGA grants No. 1/0185/11 and No. 1/1340/12 from the Scientific Grant Agency of Ministry of Education of Slovak Republic and Slovak Academy of Sciences.

Conflict of interest. The authors declare that there is no conflict of interest with the ideas put forward in the final version of manuscript.

\section{References}

Arico E, Mongue DM, Dagostino G, Moschella F, Venditti M, Kalinke U, Allen DJ, Stewart JP, Nash AA, Belardelli F, Ferantini M, Vaccine 29, 3935-3944, 2011. http://dx.doi. org/10.1016/j.vaccine.2011.03.092

Becker SD, Bennet M, Steward JP, Hurst JL, Lab. Anim. 4, 229-238, 2007. http://dx.doi.org/10.1258/002367707780378203

Blasdell K, Mc Cracken C, Morris A, Nash AA, Begon M, Bennett M, Stewart JP, J. Gen. Virol. 84, 111-113, 2003. http:// dx.doi.org/10.1099/vir.0.18731-0

Blaškovič D, Stančeková M, Svobodová J, Mistríková J, Acta Virol. 24, 468, 1980.

Blaškovič D, Staneková D, Rajčáni J, Acta Virol. 28, 225-231, 1984.

Blaškovič D, Sékeyová Z, Kožuch O, Lysý J, Labuda M, Cupalová A, Mazák V, Vlček M, Chmela J, Hubálek Z, Jirková Z, Janáková K, Biológia 42, 1973-1082, 1987.

Blaškovičová J, Tomášková J, Supolikova M, Mistríková J, Kopáček J, Acta Virol. 51, 143-148, 2007.

Čiampor F, Stančeková M, Blaškovič D, Acta Virol. 25, 101-107, 1981.

Davison AJ, Eberle R, Ehlers B, Hayward GS, McGeoch DJ, Minson AC, Pellett PE, Roizman B, Studdert MJ, Thiry E, Arch. Virol. 154, 171-177, 2009. http://dx.doi.org/10.1007/ s00705-008-0278-4

Efstathiou S, Ho YM, Hall S, Styles CJ, Scott SD, Compels NA, J. Gen. Virol. 71, 1356-1372, 1990a.

Efstathiou S, Ho YM, Minson AC, J. Gen. Virol. 71, 1355-1364, 1990b. http://dx.doi.org/10.1099/0022-1317-71-6-1355

Ehtisham S, Sunil-Chandra NP, Nash, AA, J. Virol. 67, 5247-5252, 1993.

Hamzová S, Mikovičová A, Timková J, Sabó A, Acta Chemotherapeutica 3-4, 125-128, 2005.

Hrabovská Z, Chalupková A, Mistríková J, Acta Virol. 54, 55-60, 2010a. http://dx.doi.org/10.4149/av $2010 \quad 01 \quad 55$
Hrabovská Z, Chalupková A, Čipková J, Mistríková J, Acta Virol. 54, 247-251, 2010b. http://dx.doi.org/10.4149/ av $2010 \quad 01 \quad 55$

Hricová M, Mistríková J, Acta Virol. 51, 283-287, 2007.

Hricová M, Mistríková J, Biológia 63, 753-755, 2008. http://dx.doi. org/10.2478/s11756-008-0122-Z

Hughes DJ, Kipar A, Sample JT, Stewart JP, J. Virol. 84, 3949-3961, 2010. http://dx.doi.org/10.1128/JVI.02085-09

Hughes DJ, Kipar A, Leeming GH, Bennett E, Howarth D, Cummerson JA, Papoula-Pereira R, Flanagan BF, Sample JT, Stewart JP, PloS Pathogens 7, 100113-100121, 2011.

Chalupková A, Vargová K, Hricová M, Mistríková J, Acta Vet. Brno 77, 231-237, 2008. http://dx.doi.org/10.2754/ avb200877020231

Klempa B, Mačáková K, Labuda M, Kúdelová M, Infect. Dis. Rev. 3, 31-33, 2001.

Kožuch O, Reichel M, Leššo J, Remeňová A, Labuda M, Lysý J, Mistríková J, Acta Virol. 37, 101-105, 1993.

Macrae AI, Dutia BM, Milligan S, Brownstein DG, Allen DJ, Mistríková J, Davison AJ, Nash AA and Stewart JP, J. Virol. 75, 5351-5327, 2001. http://dx.doi.org/10.1128/ JVI.75.11.5315-5327.2001

Marková G, Majerníková M, Špajdelová J, Zborník recenzovaných príspevkov, 1.zväzok biologická a environmentálna sekcia, pp. 8-10, 2007.

Matušková M, Mistríková J, Mrmusová M, Žilka N, Stančeková M, Kontseková E, Arch.Virol. 148, 1027-1036, 2003. http:// dx.doi.org/10.1007/s00705-003-0101-1

Mistríková J, Blaškovič D, Acta Virol. 29, 312-317, 1985.

Mistríková J, Remeňová A, Leššo J, Stančeková M, Acta Virol. 38, 151-156, 1994.

Mistríková J, Furdíková D, Oravcová I, Rajčáni J, Acta Virol. 40, 41-44, 1996a.

Mistríková J, Rajčáni J, Mrmusová M, Oravcová I, Acta Virol. 40, 297-301, 1996b.

Mistríková J, Mrmusová M, Acta Virol. 42, 79-82, 1998.

Mistríková J, Mrmusová M, Ďurmanová V, Rajčáni J, Viral Immunol. 12, 237-47, 1999. http://dx.doi.org/10.1089/ vim.1999.12.237

Mistríková J, Rašlová H, Mrmusová M, Kúdelová M, Acta Virol. 44, 211-226, 2000.

Mistríková J, Moško T, Mrmusová M, Acta Virol. 46, 41-46, 2002.

Mistríková J, Mrmusová-Šupolíková M, Rajčáni J, Neoplasma 51, 71-76, 2004.

Mistríková J, Blaškovičová J, Pappová M, Hricová M, Acta Virol. 50, 223-228, 2006.

Mistríková J, Rajčáni J, Central European Journal of Biology 3, 1930, 2008. http://dx.doi.org/10.2478/s11535-008-0002-0

Mrmusová M, Horváthová M, Klobušická M, Mistríková J, Acta Virol. 46, 19-24, 2002.

Mrmusová-Šupolíková M, Pappová M, Mistríková J, Acta Vet. Brno 72, 371-378, 2003.

Murphy FA, Fauquet CM, Bishop DHL, Ghabrial SA, Jarvis AW, Martelli GP, Mayo MA, Summers MD, Sixth Report of the International Committee on Taxonomy of Viruses. Springer-Verlag, Wien-NewYork, p. 586, 1995.

Nash AA, Usherwood EJ, Stewart JP, Sem. in Virol. 7, 125-130, 1996. http://dx.doi.org/10.1006/smvy.1996.0016 
Oda W, Mistríková J, Stančeková M, Dutia BM, Nash AA, Takahata H, Jin Z, Oka T, Hayashi K, Pathol. Int. 55, 558-568, 2005. http://dx.doi.org/10.1111/j.1440-1827.2005.01869.x

Pappová M, Stančeková M, Spiššáková I, Ďurmanová V, Mistríková J, Acta Virol. 48, 91-96, 2004.

Polčicová K, Hrabovská Z, Mistríková J, Tomášková J, Pastorek J, Pastoreková S, Kopaček J, Virus Res. 132, 257-262, 2008. http://dx.doi.org/10.1016/j.virusres.2007.12.004

Rašlová H, Mistríková J, Kúdelová M, Sarasin A, Blangy D, Berebbi M, Viral Immunol. 13, 313-327, 2000. http://dx.doi. org $/ 10.1089 / 08828240050144644$

Rajčáni J, Blaškovič D, Svobodová J, Čiampor F, Hučková D, Staneková D, Acta Virol. 29, 51-60, 1985.

Rajčáni J, Bustamante de Contreras LR, Svobodová J, Acta Virol. 31, 25-30, 1987.

Simas JP, Efstathiou S, Trends Microbiol. 6, 276-282, 1998. http:// dx.doi.org/10.1016/S0966-842X(98)01306-7

Spiššáková I, Vajová K, Hricová M, Mistríková J, Acta Vet. Brno 74, 353-359, 2005. http://dx.doi.org/10.2754/ avb200574030353

Stewart JP, Usherwood E, Ross A, Dyson H, Nash AA, J. Exp. Med. 185, 1941-1951, 1998. http://dx.doi.org/10.1084/ jem.187.12.1941

Stewart JP, Hughes DJ, Roaden L, Ebrahimi B, Molecular Pathogenesis of Virus infections, Cambridge University Press, pp. 319-339, 2005.
Sunil-Chandra NP, Efstathiou S, Arno J, Nash AA, J. Gen. Virol. 73, 2347-2356, 1992. http://dx.doi.org/10.1099/00221317-73-9-2347

Sunil-Chandra NP, Efstathiou S, Nash AA, Virology 193, 825-33, 1993. http://dx.doi.org/10.1006/viro.1993.1191

Sunil-Chandra NP, Arno J, Fazakerley J, Nash AA, Am. J. Pathol. 145, 818-826, 1994.

Svobodová J, Blaškovič D, Mistríková J, Acta Virol. 26, 256-263, 1982a.

Svobodová J, Stančeková M, Blaškovič D, Mistríková J, Leššo J, Russ G, Masárová P, Acta Virol. 26, 438-443, 1982b.

Štiglincová V, Chalupková A, Hrabovská Z, Čipková J, Wágnerová M, Mistríková J, Acta Virol. 55, 55-59, 2011. http://dx.doi. org/10.4149/av 2011 $01 \quad 55$

Telfer S, Bennett M, Carslake D, Helyar S, Begon M, J. Wildlife Dis. 43, 32-39, 2007.

Usherwood EJ, Ross AJ, Allen DJ, Nash AA, J. Gen. Virol. 77, 627-630, 1996a. http://dx.doi.org/10.1099/0022-131777-4-627

Usherwood EJ, Stewart JP, Nash AA, J Virol. 70, 6516-6518, 1996 b. Virgin HW, Latreille P, Wamslev P, Hallsworth K, Weck KE, Dal Canto AJ, Speck SH, J. Virol. 71, 5894-5904, 1997.

Weck KE, Kim SS, Virgin IV HW, Speck SH, J. Virol. 73, 46514661, 1999a.

Weck KE, Kim SS, Virgin IV HW, Speck SH, J. Virol. 73, 3273-83, 1999b. 